\title{
Impact of Postharvest Hot Water or Ethanol Treatment of Table Grapes on Gray Mold Incidence, Quality, and Ethanol Content
}

\author{
F. Mlikota Gabler, Institute for Adriatic Crops, Put Duilova 11, 21000 Split, Croatia; and J. L. Smilanick, \\ J. M. Ghosoph, and D. A. Margosan, United States Department of Agriculture-Agricultural Research Service, San \\ Joaquin Valley Agricultural Sciences Center, Parlier, CA 93648
}

\begin{abstract}
Mlikota Gabler, F., Smilanick, J. L., Ghosoph, J. M., and Margosan, D. A. 2005. Impact of postharvest hot water or ethanol treatment of table grapes on gray mold incidence, quality, and ethanol content. Plant Dis. 89:309-316.

The influence of brief immersion of grape berries in water or ethanol at ambient or higher temperatures on the postharvest incidence of gray mold (caused by Botrytis cinerea) was evaluated. The incidence of gray mold among grape berries that were untreated, or immersed for $1 \mathrm{~min}$ in ethanol $(35 \% \mathrm{vol} / \mathrm{vol})$ at 25 or $50^{\circ} \mathrm{C}$, was $78.7,26.2$, and 3.4 berries $/ \mathrm{kg}$, respectively, after 1 month of storage at $0.5^{\circ} \mathrm{C}$ and 2 days at $25^{\circ} \mathrm{C}$. Heated ethanol was effective up to $24 \mathrm{~h}$ after inoculation, but less effective when berry pedicels were removed before inoculation. Rachis appearance, epicuticular wax content and appearance, and berry shatter were unchanged by heated ethanol treatments, whereas berry color changed slightly and treated grape berries were more susceptible to subsequent infection. Ethanol and acetaldehyde contents of grape berries were determined 1,7 , and 14 days after storage at $0.5^{\circ} \mathrm{C}$ following treatment for 30 or $90 \mathrm{~s}$ at 30 , 40 , or $50^{\circ} \mathrm{C}$ with water, or $35 \%$ ethanol. Highest residues $(377 \mu \mathrm{g} / \mathrm{g}$ of ethanol and $13.3 \mu \mathrm{g} / \mathrm{g}$ of acetaldehyde) were in berries immersed for $90 \mathrm{~s}$ at $50^{\circ} \mathrm{C}$ in ethanol. Among ethanol-treated grape berries, the ethanol content declined during storage, whereas acetaldehyde content was unchanged or increased. Untreated grape berries initially contained ethanol at $62 \mu \mathrm{g} / \mathrm{g}$, which then declined. Acetaldehyde content was $0.6 \mu \mathrm{g} / \mathrm{g}$ initially and changed little during storage.
\end{abstract}

Postharvest gray mold, caused by Botrytis cinerea Pers., is a major cause of decay of table grape berries $(6,21,32)$. It develops during both commercial cold storage, typically at -0.5 to $0^{\circ} \mathrm{C}$, and subsequent transport and marketing at warmer temperatures. B. cinerea is troublesome because it can grow at cold temperatures and spread rapidly by aerial mycelial growth among the fruit.

Sulfur dioxide gas is used to control gray mold. In California, it is first applied from compressed gas cylinders to fumigate

Corresponding author: F. Mlikota Gabler

E-mail: fgabler@fresno.ars.usda.gov

Current address of F. Mlikota Gabler: United States Department of Agriculture-Agricultural Research Service, San Joaquin Valley Agricultural Sciences Center, 9611 S. Riverbend Ave. Parlier, CA 93648.

All experiments were conducted at USDA, San Joaquin Valley Agricultural Sciences Center, Parlier, CA.

A portion of this work was financed by a USAIsrael Binational Agricultural Research and Development Fund Project (IS-3271-01R).

Accepted for publication 26 October 2004.

DOI: 10.1094/PD-89-0309

This article is in the public domain and not copyrightable. It may be freely reprinted with customary crediting of the source. The American Phytopathological Society, 2005 grape fruit in precooling chambers, then at weekly intervals in storage rooms, and occasionally within truck trailers and van containers during transport (22). It also is generated from sulfite-containing pads within grape packages. Concerns about sulfite residues in grape berries and other foods caused sulfur dioxide to be removed from the United States Food and Drug Administration generally recognized as safe (GRAS) compound list (1). It was reclassified as a pesticide with a residue tolerance of $10 \mathrm{mg} / \mathrm{kg}$ for table grape fruit by the United States Environmental Protection Agency (2). Organic growers are prohibited from using sulfur dioxide, and this segment of grape production is growing rapidly (41). The fungicides organic growers can apply before harvest are limited and do not significantly control postharvest gray mold. Therefore, organic grape berries are particularly vulnerable to postharvest decay and are known to have a short life after harvest. Other issues that make the development of an alternative to sulfur dioxide important include eliminating the common bleaching and rachis injury to grape berries caused by sulfur dioxide, and avoiding sulfite residues that exceed the tolerance, although high residues are uncommon $(4,22)$.

Ethanol occurs in many food products and additives. It is an approved substance for use as a disinfectant or sanitizer in organic crop production by the United
States Department of Agriculture (USDA) National Organic Program (2001). The flammability limit of ethanol in air is $33,000 \mathrm{ppm}$ ( $\mathrm{vol} / \mathrm{vol}$ ) and the air in manned workplaces cannot contain ethanol at more than $1,000 \mathrm{ppm}$ ( $\mathrm{vol} / \mathrm{vol} ; 3)$. Therefore, reducing the concentration used in applications is important. Ethanol has been reported to effectively control postharvest table grape decay caused by $B$. cinerea, Alternaria alternata, and Aspergillus niger when applied after $(17,21,29,30)$ or before (18) harvest. Effective concentrations to control gray mold were 30 to $50 \%(\mathrm{vol} / \mathrm{vol})$ and treatment did not harm grape berries when examined up to 4 weeks later $(17,21,30)$. When applied on Cabernet Sauvignon grape fruit at veraison, $5 \%$ (vol/vol) ethanol increased the accumulation of anthocyanins during berry ripening (14).

Brief heated water treatments have been studied extensively for the control of many postharvest diseases $(6,7,16,35)$. An important issue associated with the implementation of thermal treatment is that the temperatures needed to control diseases are often close to those injurious to the commodity (6). Use of treatments where hot water and ethanol are combined, so as to reduce both the ethanol concentrations and water temperatures, deserves evaluation because this approach could conceivably reduce safety issues, improve the efficacy of the treatment compared with either ethanol or hot water alone, and minimize injuries to the treated products. The synergistic effect of hot water treatment combined with low ethanol concentrations to control the postharvest decay of strawberry fruit (23), citrus fruit (38), and stone fruit (24) has been demonstrated. Mlikota Gabler et al. (28) reported the $\mathrm{LD}_{50}$ (lethal dose or concentration of ethanol that killed $50 \%$ spores) was reduced from $20 \%$ at $25^{\circ} \mathrm{C}$ to $2 \%$ at $50^{\circ} \mathrm{C}$. Because of the enhanced antifungal activity of this combination, lower temperatures that are usually less injurious to the fruit can be employed. Immersion of grape berries in heated lowconcentration ethanol solutions effectively controlled gray mold on grape (17).

Our objectives addressed several aspects important to the practical implementation of a heated ethanol treatment. First, we examined the effectiveness of water or ethanol solutions at ambient or higher temperatures to control postharvest gray 
mold on table grape, and determined how long the interval can be between $B$. cinerea inoculation and ethanol treatment to still effectively control gray mold. It is important because some time will pass between harvest, when presumably many infections occur (13), and when grape berries can be treated in packing facilities. Then, we determined the effectiveness of treatments applied to berries with large natural wounds caused by the pedicel removal, because some packages in the market are composed of de-stemmed berries. Finally, we evaluated the susceptibility of treated grape berries to subsequent $B$. cinerea infections, the impact of these treatments on some quality parameters, and quantified the ethanol and acetaldehyde contents and their persistence in grape fruit after heated ethanol treatment.

\section{MATERIALS AND METHODS}

Fruit. Organically grown Crimson Seedless grape berries were harvested from a vineyard in Tulare County, CA, and Autumn Seedless, Diamond Muscat, and Emperor grape berries were harvested from a USDA vineyard in Fresno County, CA.

Inoculum preparation. A $B$. cinerea isolate from grape 1440 (provided by Themis Michailides of the Kearney Agricultural Center, Parlier, CA) was grown on potato dextrose agar for 2 weeks at $23^{\circ} \mathrm{C}$. Spores were rubbed from the agar surface with a glass rod after a small volume of sterile water plus surfactant $0.05 \%$ (wt/vol) Triton X-100 was added. The spore suspension was vigorously shaken and then filtered through four layers of cheesecloth. The suspension was diluted with sterile water to an absorbance of 0.25 at $425 \mathrm{~nm}$ as determined by a spectrophotometer. This density contained $1.0 \times 10^{6}$ co$\mathrm{nidia} / \mathrm{ml}$ and was diluted with sterile water to obtain the desired spore concentrations. A volume of $50 \mathrm{ml}$ of inoculum per 1,200 berries was applied with an air-brush sprayer.

Treatment of single detached berries. In the first experiment, the effectiveness of ethanol and water treatments at 25 or $50^{\circ} \mathrm{C}$ on gray mold incidence on Autumn Seedless grape berries after inoculation 2, 8, 24, or $48 \mathrm{~h}$ prior to treatment was determined. Berries were either cut from rachis with pedicel intact, or pulled from rachis (pedicel detached), which exposed the berry flesh and enabled wound inoculation to occur. The berries were then spray inoculated with $B$. cinerea as described previously. Inoculated berries were incubated at $15^{\circ} \mathrm{C}$ in a covered plastic box until treated. Fruit in each treatment were immersed for $1 \mathrm{~min}$ in water or $35 \%$ (vol/vol) ethanol at 25 or $50^{\circ} \mathrm{C}$. Seven days following inoculation, berries were examined for gray mold decay. The experiment was conducted twice.

In the second experiment, the susceptibility of ethanol- or hot water-treated sin- gle Emperor berries to subsequent infection by $B$. cinerea was determined. Small clusters were immersed for $3 \mathrm{~min}$ in water or $50 \%(\mathrm{vol} / \mathrm{vol})$ ethanol at 25 or $50^{\circ} \mathrm{C}$; then, 50 single berries with the pedicel intact were cut from the clusters and inoculated by spraying them to runoff with $1.25 \times 10^{5}$ conidia/ml after $2 \mathrm{~h}, 2$ days, or 6 days. The berries were placed on wire racks within a plastic box that contained a moist paper towel to maintain a high relative humidity during incubation. After 7 days at $15^{\circ} \mathrm{C}$, gray mold incidence was determined by counting the number of infected berries. The experiment was done three times.

Treatment of table grape clusters. Crimson Seedless grape berries were divided into small clusters of approximately $100 \mathrm{~g}$ each, and randomized so that a portion of each cluster was represented in each replicate. Grape clusters were inoculated by briefly spraying them with a suspension of approximately $1 \times 10^{5} \mathrm{co}-$ nidia/ml $2 \mathrm{~h}$ prior to treatment, and then about $800 \mathrm{~g}$ of grape clusters were placed in ventilated polyethylene bags. Each replicate consisted of three bags of grape fruit and each treatment was applied to four replicates. The bags of grape clusters were immersed in 15 liters of $35 \%$ ( $\mathrm{vol} / \mathrm{vol})$ ethanol at 25 or $50^{\circ} \mathrm{C}$ for $60 \mathrm{~s}$. After treatment, the grape clusters were air dried on a wire rack, then repackaged in new ventilated polyethylene bags and arranged in commercial corrugated fiberboard boxes. Boxes were loosely covered with large polyethylene bags to retard moisture loss and placed in storage at $0.5^{\circ} \mathrm{C}$ for 30 days. After storage, boxes of grape fruit were placed at $24^{\circ} \mathrm{C}$ for 2 days, then the incidence of infected berries and the quality of the grape fruit were determined. The experiment was repeated twice.

Quality evaluation. Crimson Seedless grape fruit intended for quality evaluation were randomized, treated, packaged, and stored as described previously for table grape clusters, but were not inoculated. Each replicate consisted of three bags of grape fruit and each treatment was applied to four replicates. After 30 days of storage at $0.5^{\circ} \mathrm{C}$ and an additional 2 days at $24^{\circ} \mathrm{C}$, the quality of the grape fruit was examined. The number of shattered berries was determined by gently shaking each cluster three times, then the number of detached berries was counted and the number of shattered berries per kilogram for each replicate was calculated. Two appearance ratings were applied to the rachis, one to the primary rachis, and a second rating was applied to the secondary rachis branches and pedicels. Visual scales of 1 to 5 were used, where 1 = green and fresh; 2 = green and partially dry; $3=$ dry and brownishgreen; 4 = dry and brown; and $5=$ very dry, brown, and brittle. For color evaluation, berries with the pedicel attached were randomly cut from Crimson Seedless grape clusters and immersed in the $35 \%$ ( $\mathrm{vol} / \mathrm{vol}$ ) ethanol at 25 or $50^{\circ} \mathrm{C}$ for $60 \mathrm{~s}$ or were left untreated. Each treatment consisted of 60 berries. Berries were placed in cluster bags and included in the boxes with other uninoculated grape berries in this experiment, and stored at $0.5^{\circ} \mathrm{C}$. Their color was evaluated after 30 days. Color was recorded as CIELab color space (26) determined with a surface color analyzer (Model CR-200; Minolta Corp. Ramsey, $\mathrm{NJ})$. The quality experiment was repeated twice, with the exception of the color measurements, which were performed once.

Wax quantification. The modified methods of Baker and Bateman (5) and Percival and coworkers (34) were used to quantify the amount of wax of Diamond Muscat grape berries previously immersed for $3 \mathrm{~min}$ in water or $50 \%$ (vol/vol) ethanol at 25 or $50^{\circ} \mathrm{C}$. Several epidermal disks, 7 $\mathrm{mm}$ in diameter, were cut with a cork borer from different parts of each berry. The wax content of three replicates of 50 disks each was determined. Cuticle and wax layers were separated from underlying tissues by soaking the disks for $24 \mathrm{~h}$ at $30^{\circ} \mathrm{C}$ in 2.5 $\mathrm{ml}$ of a digestion solution containing $0.1 \%$ (wt/vol) cellulase (Sigma-Aldrich, St. Louis) and $0.5 \%$ (vol/vol) pectinase (Sigma-Aldrich) dissolved in $0.1 \mathrm{M}$ sodium acetate buffer ( $\mathrm{pH} 4)$. The disks of digestion-resistant material (cuticle plus epicuticular wax) were collected on a metal screen and rinsed with deionized water until clean. The disks were dried in air, after which the epicuticular wax was dissolved by immersion of the disks in 2 $\mathrm{ml}$ of $100 \%$ chloroform for $24 \mathrm{~h}$ to separate it from the cuticle. The wax dissolved in chloroform was transferred to preweighed beakers, evaporated in air, then placed in an oven at $100^{\circ} \mathrm{C}$ for $24 \mathrm{~h}$, after which their weights were recorded. The experiment was conducted once.

Scanning electron microscopy: wax observation. Pieces of berry skin $3 \mathrm{~mm}^{2}$ in size that consisted of cuticle with epidermal wax and epidermal and hypodermal tissues were excised from Autumn Seedless or Emperor Seedless grape berries previously treated for $3 \mathrm{~min}$ in: (i) water at $25^{\circ} \mathrm{C}$, (ii) water at $50^{\circ} \mathrm{C}$, or (iii) $50 \%(\mathrm{vol} / \mathrm{vol})$ ethanol at $50^{\circ} \mathrm{C}$. The pieces were plunge frozen in liquid nitrogen, then freeze dried for $24 \mathrm{~h}$. The dried samples were mounted on aluminum stubs and coated with approximately $12 \mathrm{~nm}$ of gold with SPI-module sputter coater (Structure Probe, Inc., West Chester, PA). Samples were examined with a scanning electron microscope (SEM; Model S-3500N; Hitachi, Tokyo) operating at $15 \mathrm{kV}$ and images were digitally recorded.

Observation of inoculum on grape berries. Intact or wounded Crimson Seedless berries were inoculated by spraying them with a suspension of $1 \times 10^{6} \mathrm{co}-$ $\mathrm{nidia} / \mathrm{ml}$. Wounds were made by removing 
the epidermis and several cell layers of the hypodermis with a razor blade. Berries were incubated for $24 \mathrm{~h}$ in a small plastic container with damp paper towels to maintain high humidity. For SEM examination, pieces of epidermal and hypodermal tissue $5 \mathrm{~mm}^{2}$ in area and $2 \mathrm{~mm}$ thick were excised from the intact or wounded tissue, then fixed overnight in $4 \%$ ( $\mathrm{vol} / \mathrm{vol})$ glutaraldehyde in $0.2 \mathrm{M}$ phosphate buffer (PB), $\mathrm{pH} 7.0$, and postfixed for $1.5 \mathrm{~h}$ in $1 \%$ (wt/vol) osmium tetroxide in PB. Pieces were dehydrated in an ethanol series and then critical point dried (Model CPD2; Ted Pella, Inc., Redding, CA). The dried tissues were mounted on stubs, sputtercoated with approximately $12 \mathrm{~nm}$ of gold, and examined with an SEM operating at $10 \mathrm{kV}$. In all, 400 conidia on intact berry surfaces and 300 conidia on cut berry surfaces were examined for germination and, when germinated, their germ tubes were measured. Images obtained were digitally recorded.

Ethanol content in stored grape fruit. Crimson Seedless grape clusters were divided in smaller clusters of about $100 \mathrm{~g}$ each and randomized so that a portion of each cluster was represented in each replicate. Each replicate consisted of one perforated polyethylene grape cluster bag containing approximately $600 \mathrm{~g}$ of grape berries, and four replicates were prepared for each treatment. The bags of grape fruit were immersed in 15 liters of $35 \%$ $(\mathrm{vol} / \mathrm{vol})$ ethanol at 30,40 , or $50^{\circ} \mathrm{C}$ for 30 or $90 \mathrm{~s}$. Control grape fruit were not treated. After treatment, the grape clusters were removed from the bags and dried in air on a wire rack, then repackaged in new polyethylene grape cluster bags, arranged in commercial corrugated fiberboard boxes, and placed in storage at $0.5^{\circ} \mathrm{C}$.

Samples for ethanol and acetaldehyde analysis were taken after 1,7 , and 14 days of storage. For each analysis, in a $10^{\circ} \mathrm{C}$ temperature-controlled room, all of the berries from within each replicate bag were pulled from rachis and promptly homogenized in a blender at high speed for $90 \mathrm{~s}$. The macerate was poured into $400-\mathrm{ml}$ beakers and placed on ice, typically for 20 min, until a liquid phase of grape juice separated from the foamy supernatant. Then, $50 \mathrm{ml}$ of the liquid phase was placed in a polycarbonate vial, capped, and frozen at $-20^{\circ} \mathrm{C}$ until analyzed. The ethanol and acetaldehyde contents in juice preparations were determined by headspace analysis using a gas chromatograph (model GC14A; Shimadzu Scientific Instrument Co., Kyoto, Japan) equipped with a 4-mm-by2-m glass column (packing 10\% AT-1000 on 80/100, Chromosorb W-AW; Alltech Associates Inc., Deerfield, IL) with a column nitrogen flow rate of $20 \mathrm{ml} / \mathrm{min}$. A flame ionization detector operating at $275^{\circ} \mathrm{C}$ was used with air and hydrogen flow rates of 500 and $50 \mathrm{ml} / \mathrm{min}$, respectively. The oven and injector temperatures were 85 and $250^{\circ} \mathrm{C}$, respectively. Berry juice preparations were thawed in a water bath at room temperature. A volume of 1 $\mathrm{ml}$ was placed into a 20 -ml-capacity glass vial. The vial was closed, placed in a water bath at $60^{\circ} \mathrm{C}$ for $10 \mathrm{~min}$, and then a volume of $0.5 \mathrm{ml}$ of the headspace sample was removed through a silicone septum in the cap of the vial and immediately injected into the gas chromatograph. Acetaldehyde and ethanol were detected according to their retention times of authentic standards, typically 0.8 and $3.2 \mathrm{~min}$ after injection, respectively. Berry acetaldehyde and ethanol contents were quantified using a curve prepared from standards prepared in double-distilled water. The experiment was conducted once.

Statistical analysis. The incidence of gray mold was analyzed by a three-way analysis of variance applied to the arcsin of the square root of the proportion of infected berries. Means were separated by Fisher's Protected least significant difference $(P=0.05$; SuperANOVA; Abacus Concepts, Inc., Berkeley, CA). Actual

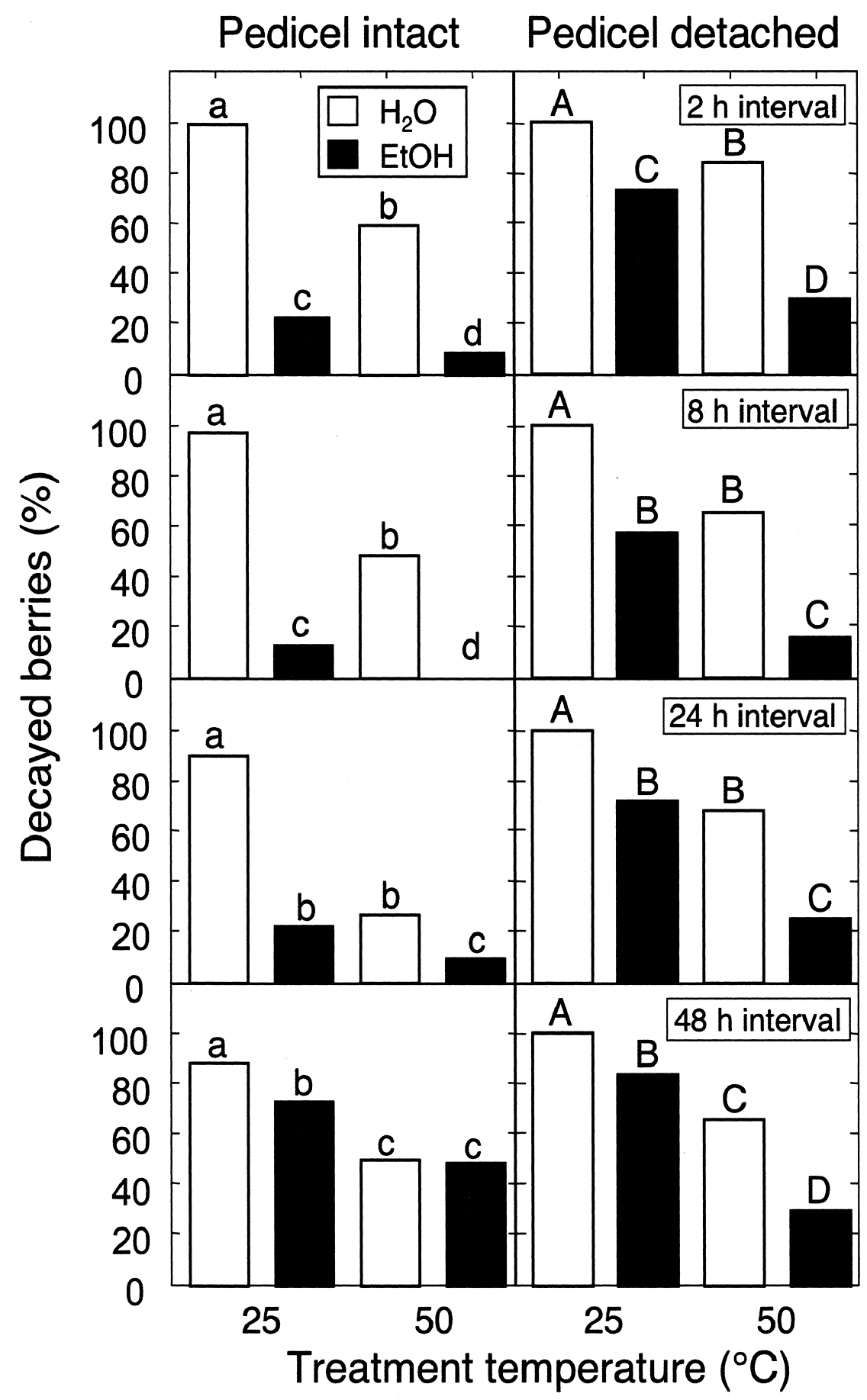

Fig. 1. Gray mold incidence on single Autumn Seedless berries incubated for 7 days at $15^{\circ} \mathrm{C}$. Prior to inoculation, the pedicel was intact or removed. Berries were inoculated by spraying with $1 \times 10^{6}$ conidia of Botrytis cinerea/ml, then immersed after 2, 8, 24, or $48 \mathrm{~h}$ in water or $35 \%$ ethanol (EtOH) for $60 \mathrm{~s}$. 
values are shown. Significant differences in ethanol and acetaldehyde contents between different storage periods were separated by unpaired $t$ tests $(P \leq 0.05)$.

\section{RESULTS}

The incidence of gray mold after immersion of grape berries in water at $25^{\circ} \mathrm{C}$ was typically $90 \%$ or higher (Fig. 1). Treatment with water at $50^{\circ} \mathrm{C}$ significantly reduced gray mold incidence, but its effectiveness was poor regardless of the interval pedicel was present or absent on the inoculated berries. Treatment with $35 \%$ (vol/vol) ethanol at $25^{\circ} \mathrm{C}$ also significantly reduced gray mold incidence. It was significantly superior to water at $50^{\circ} \mathrm{C}$ when either the pedicel was intact on the inoculated berries or when the interval between inoculation between inoculation and treatment or if the

and treatment was less than $24 \mathrm{~h}$. Treatment with $35 \%$ ( $\mathrm{vol} / \mathrm{vol}$ ) ethanol at $50^{\circ} \mathrm{C}$ was significantly superior to the other treatments and the magnitude of the difference was usually large, except when the interval between inoculation and treatment was $48 \mathrm{~h}$ and the pedicels on the inoculated berries were intact.

An increase in solution temperature significantly improved the control of gray mold in both surface- and wound-inoculated berries among all inoculation intervals (Fig. $1 ; P=0.0001$ ). When treatments were applied at the same temperatures, the addition of ethanol significantly reduced the number of decayed berries compared with water alone among all inoculation intervals (Fig. $1 ; P=0.0001$ ). When heat and ethanol were combined, it resulted in significantly lower gray mold incidence

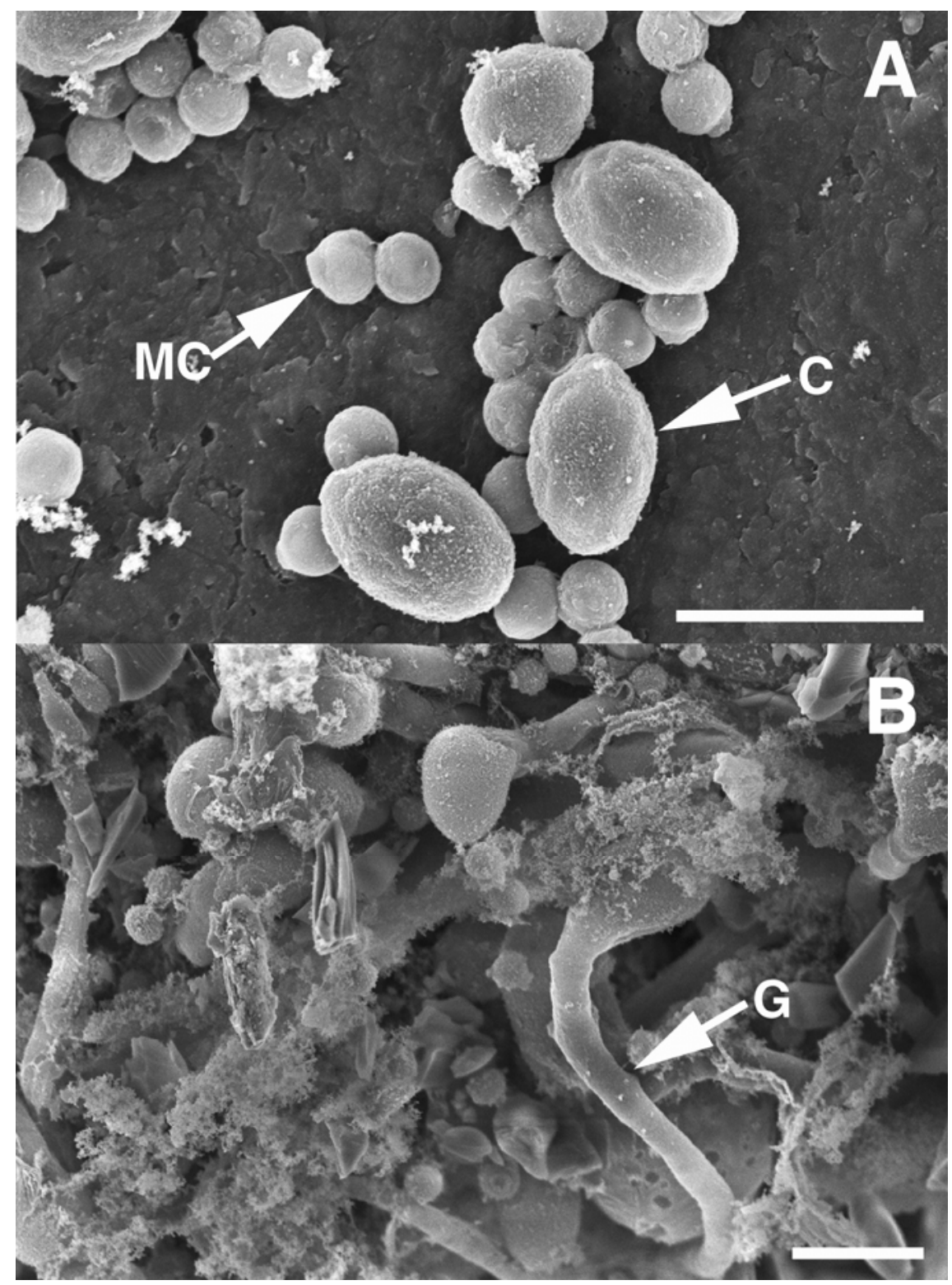

Fig. 2. Botrytis cinerea conidia on intact or wounded Autumn Seedless berries after $24 \mathrm{~h}$ of incubation at $25^{\circ} \mathrm{C}$ and high humidity as viewed by a scanning electron microscope. A, Macroconidia (C) and microconidia (MC) on the intact surface of a grape berry. No germ tubes are present. B, Macro- and microconidia on the surface of a cut grape berry. Germ tubes (G) from the macroconidia are growing into the cut surface. Scale bar $=10 \mu \mathrm{m}$. than when each was applied separately (Fig. 1).

The presence of a wound significantly influenced the effectiveness of immersion of single Autumn Seedless berries in water or ethanol solutions. When berries were inoculated with the pedicel intact, gray mold incidence was significantly lower $(P$ $=0.001)$ compared with the berries inoculated without pedicels, where a large wound was created by the removal of the pedicel. The exception was the treatment of berries $48 \mathrm{~h}$ after inoculation in heated $35 \%$ (vol/vol) ethanol (Fig. 1).

$B$. cinerea conidia germinated faster and in greater proportion when they were deposited on exposed berry flesh without the skin than when they were deposited on the intact berry cuticle (Fig. 2). Germination on intact berries or exposed berry flesh after $24 \mathrm{~h}$ was 3 and $65 \%$, respectively. The germ tubes that emerged from conidia deposited on intact berries were 3.8 to 8.4 $\mu \mathrm{m}$ in length, with an average of $5.8 \mu \mathrm{m}$. Those that emerged from conidia deposited on the exposed flesh of the berries were much longer, 3.3 to $109.0 \mu \mathrm{m}$ in length, with an average of $19.6 \mu \mathrm{m}$. Many of the conidial germ tube lengths on the wounded berries were impossible to measure, because they had penetrated the tissue to an unknown depth. None of the conidial germ tubes on intact berry surfaces had penetrated the surface $24 \mathrm{~h}$ after inoculation.

Immersion of grape fruit in $35 \%$ (vol/vol) ethanol at 25 or $50^{\circ} \mathrm{C}$, or in water at $50^{\circ} \mathrm{C}$, significantly $(P=0.0001)$ increased the susceptibility of berries to subsequent infection with $B$. cinerea, compared with those immersed in water alone at $25^{\circ} \mathrm{C}$, although the magnitude of the increase was small (Fig. 3).

The appearance of epicuticular wax was not changed after immersion for $3 \mathrm{~min}$ in water or $50 \%(\mathrm{vol} / \mathrm{vol})$ ethanol at 25 or $50^{\circ} \mathrm{C}$ of Emperor and Autumn Seedless berries (not shown). The mean wax contents of Diamond Muscat grape berries were not statistically different; they were $1.052,1.094,1.038$, or $1.064 \mu \mathrm{g} / \mathrm{mm}^{2}$ after immersion in water at $25^{\circ} \mathrm{C}$, ethanol at $25^{\circ} \mathrm{C}$, water at $50^{\circ} \mathrm{C}$, or ethanol at $50^{\circ} \mathrm{C}$, respectively.

The natural ethanol content of untreated Crimson Seedless grape berries initially was $62 \mu \mathrm{g} / \mathrm{g}$ and declined to $10 \mu \mathrm{g} / \mathrm{g}$ after 14 days (Fig. 4). The natural acetaldehyde content of untreated grape berries was 0.6 $\mu \mathrm{g} / \mathrm{g}$ initially and changed little during storage. Treatment at $50^{\circ} \mathrm{C}$ in $35 \%$ ( $\left.\mathrm{vol} / \mathrm{vol}\right)$ ethanol greatly increased ethanol and acetaldehyde contents, especially when duration was $90 \mathrm{~s}$. After 14 days of storage following treatment at $50^{\circ} \mathrm{C}$ for $90 \mathrm{~s}$, the ethanol content had significantly $(P=0.0284$; unpaired $t$ test) declined from 342 to $231 \mu \mathrm{g} / \mathrm{g}$, whereas acetaldehyde content had significantly $(P=0.0476$; unpaired $t$ test $)$ increased from 9.8 to $13.3 \mu \mathrm{g} / \mathrm{g}$. 
Immersion of whole Crimson Seedless clusters in $35 \%$ (vol/vol) ethanol significantly reduced postharvest gray mold after 30 days storage at $0.5^{\circ} \mathrm{C}$ and 2 days at $25^{\circ} \mathrm{C}$. When grape berries were immersed in ethanol at $50^{\circ} \mathrm{C}$, gray mold incidence was significantly lower then when they were immersed in ethanol at $25^{\circ} \mathrm{C}$ (Fig. 5). There were no significant differences in number of shattered berries between untreated clusters or those immersed in ethanol solutions (Fig. 5). Primary or secondary rachis appearance was not significantly impacted by immersion in ethanol solutions. The visual appearance ratings of grape berries after immersion in $35 \%$ ( $\mathrm{vol} / \mathrm{vol}$ ) ethanol at 25 or $50^{\circ} \mathrm{C}$, or untreated, were $2.8,2.6$, or 3.0, respectively, for primary rachis, and 3.8, 3.6, or 3.7, respectively, for secondary rachis. After immersion in heated ethanol and 30 days of storage at $0.5^{\circ} \mathrm{C}$, the "L" value decreased and the hue angle increased, resulting in darker, deeper red color with more orange component than after other treatments (Fig. 6).

\section{DISCUSSION}

Immersion of grape fruit in ethanol solutions effectively controlled gray mold. Infections were controlled by both cool and warm ethanol on berries inoculated with the pedicel intact. Only heated ethanol controlled gray mold on berries that were wounded by detachment of the pedicel before inoculation. Heated ethanol treatments could be applied up to $24 \mathrm{~h}$ after inoculation and remain effective. Immersion of grape fruit in 30 to $35 \%$ ethanol ( $\mathrm{vol} / \mathrm{vol})$ solutions at ambient temperatures has been reported to control postharvest gray mold $(21,29,30)$.

In our work, heated-water treatment of table grape berries significantly reduced the incidence of gray mold, although its effectiveness was inadequate and significantly inferior to heated ethanol. Heatedwater treatments at $50^{\circ} \mathrm{C}$ can be effective; for example, treatment with water at $50^{\circ} \mathrm{C}$ for 3 min completely inhibited germination of $B$. cinerea, and significantly reduced subsequent decay of bell pepper (15). For better control of decay of table grape berries with hot water, temperatures higher than $50^{\circ} \mathrm{C}$ would be needed but it could injure the berries. We observed objectionable berry darkening after water treatments of Crimson Seedless grape fruit at $60^{\circ} \mathrm{C}$ (data not shown). In prior work, we found that brief water treatments at $60^{\circ} \mathrm{C}$ or more effectively controlled green mold, caused by Penicillium digitatum, on citrus fruit (39). Schirra et al. (35) reported that immersion of citrus fruit in water for 2 min at $50^{\circ} \mathrm{C}$ was effective only against superficial infections and ineffective on deeper infections. Inactivation of fungi by heat treatments depends on the temperature and duration of the treatment (6). The heat treatment lasts as long as the fruit is in

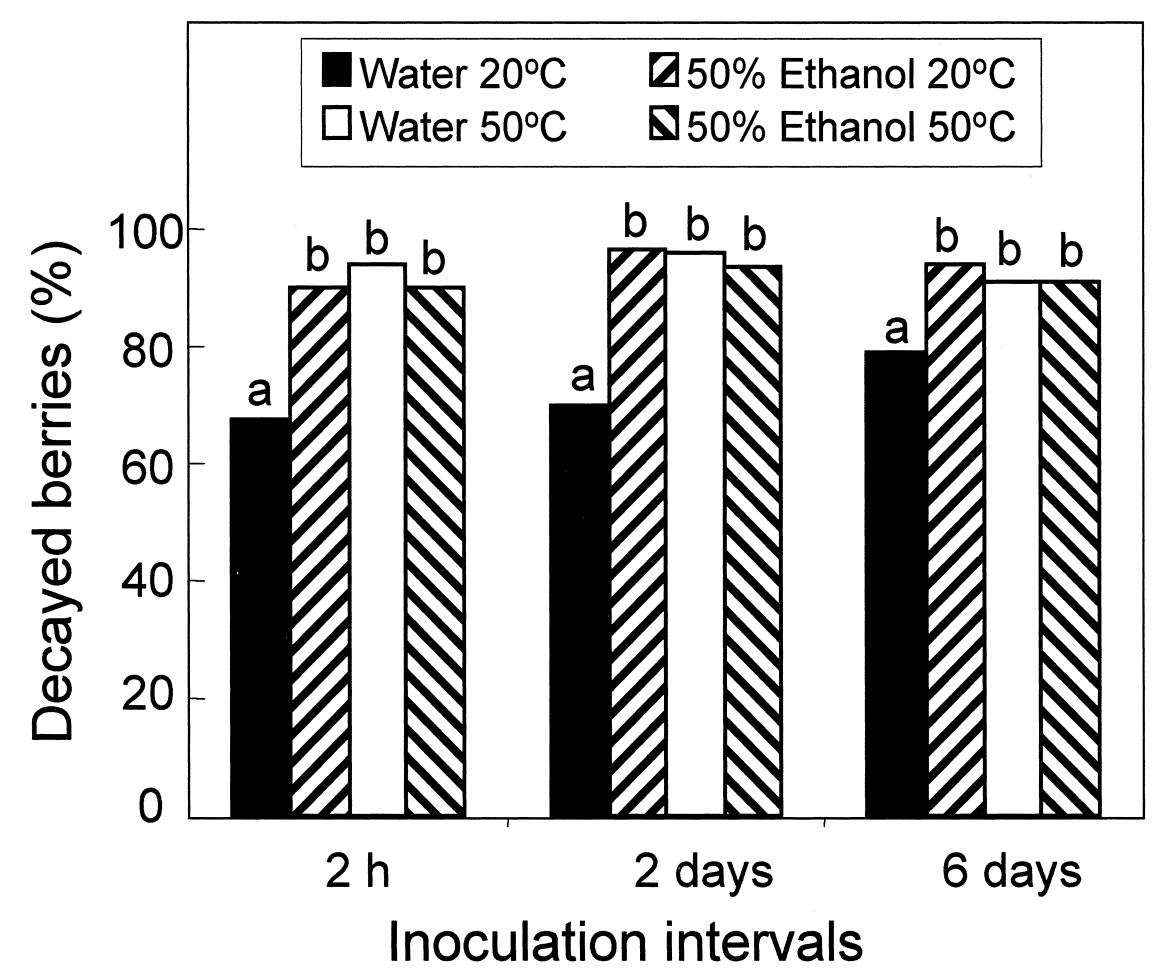

Fig. 3. Gray mold incidence on single Emperor berries. Berries were previously immersed for 3 min in water or $50 \%$ ethanol. After 2 h, 2 days, or 6 days, treated berries were inoculated by spraying with $1 \times$ $10^{6}$ conidia of Botrytis cinerea $/ \mathrm{ml}$ and incubated for 7 days at $15^{\circ} \mathrm{C}$.

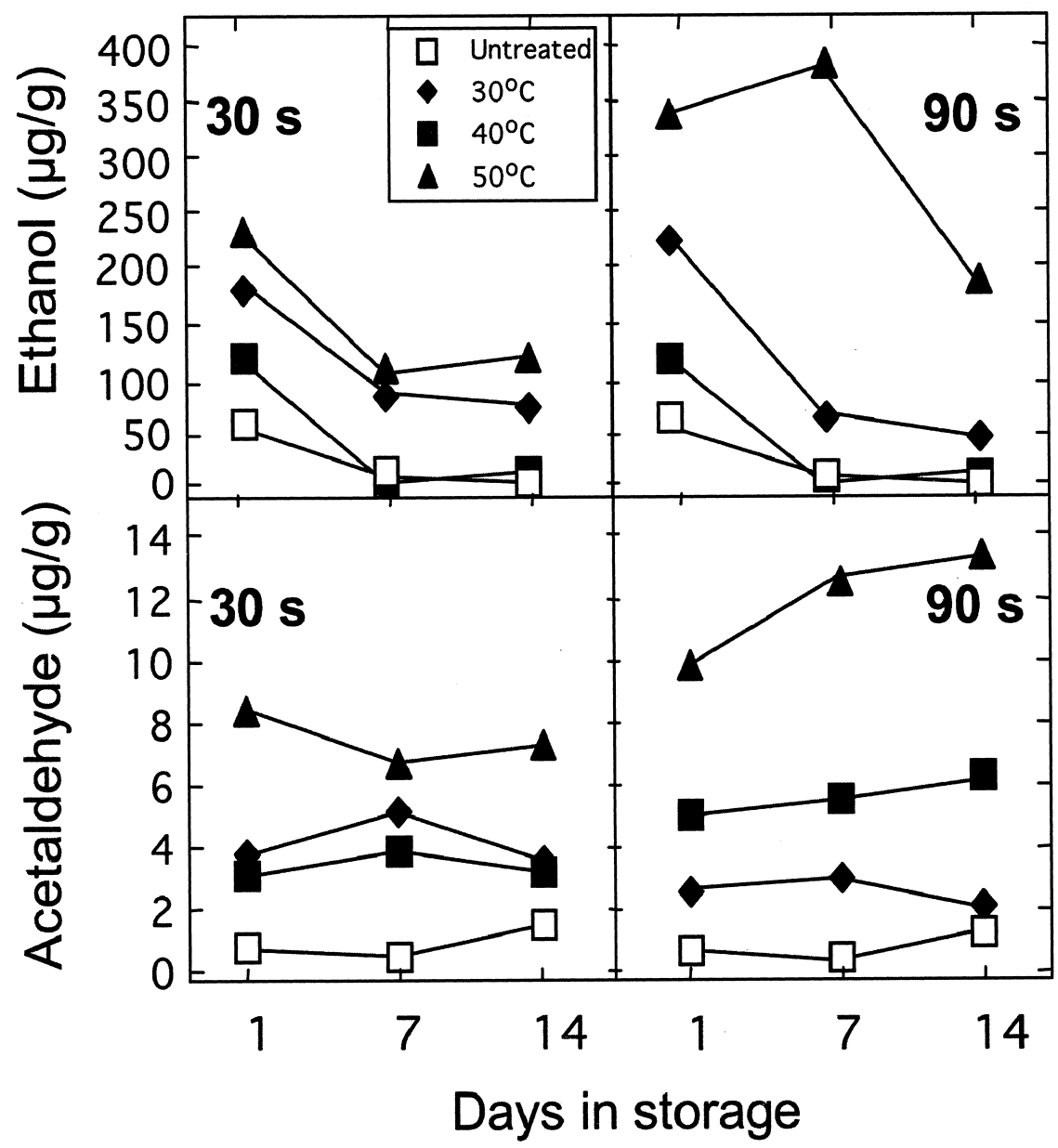

Fig. 4. Ethanol and acetaldehyde contents of Crimson Seedless grape berries. Grape clusters were immersed for $1 \mathrm{~min}$ in water or $35 \%$ ethanol, then air dried and stored at $0.5^{\circ} \mathrm{C}$ for 1,7 , or 14 days. 


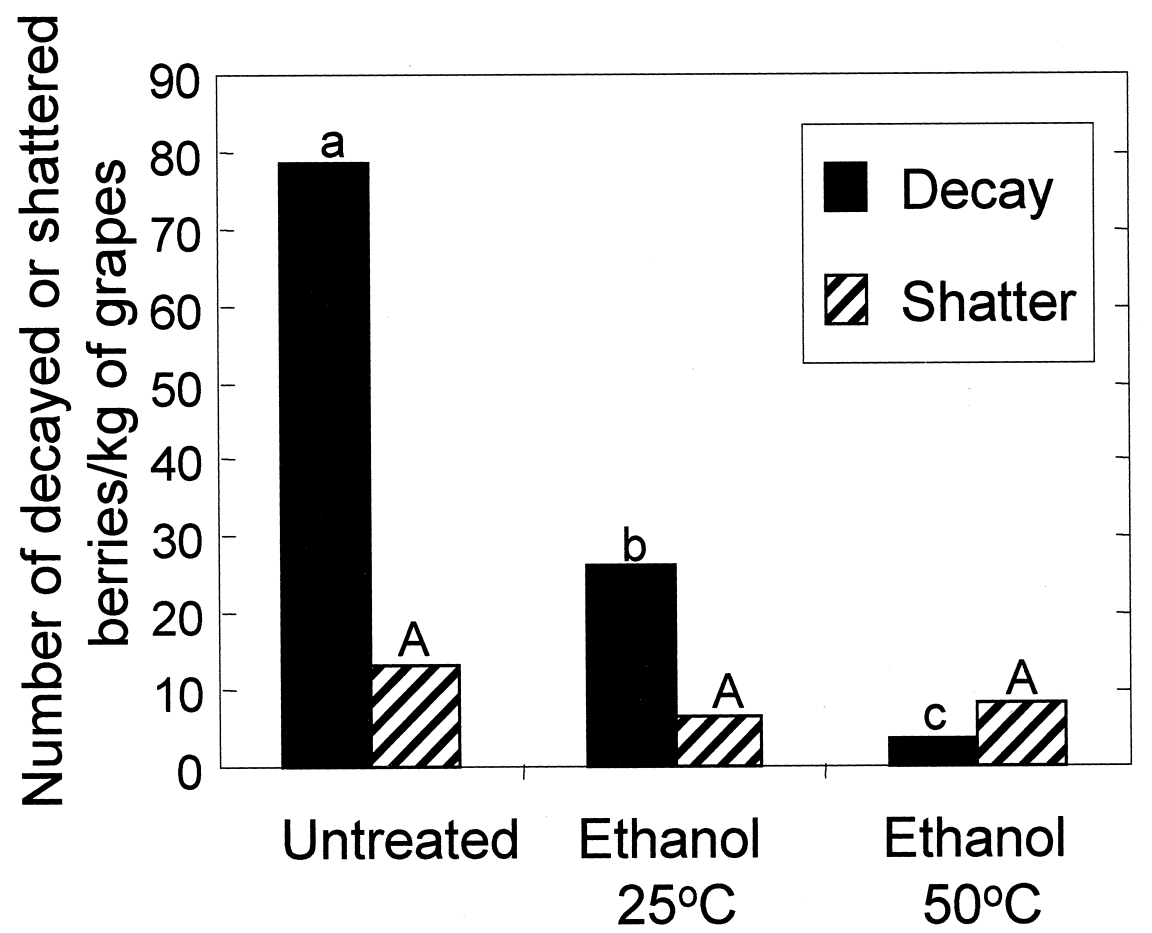

Fig. 5. Gray mold incidence on Crimson Seedless clusters after 30 days of storage at $0.5^{\circ} \mathrm{C}$ and 2 days at $25^{\circ} \mathrm{C}$. Grape clusters were inoculated by spraying them with $1 \times 10^{4}$ conidia of Botrytis cinerea $/ \mathrm{ml}$, then immersed in $35 \%$ ethanol for $60 \mathrm{~s}$.

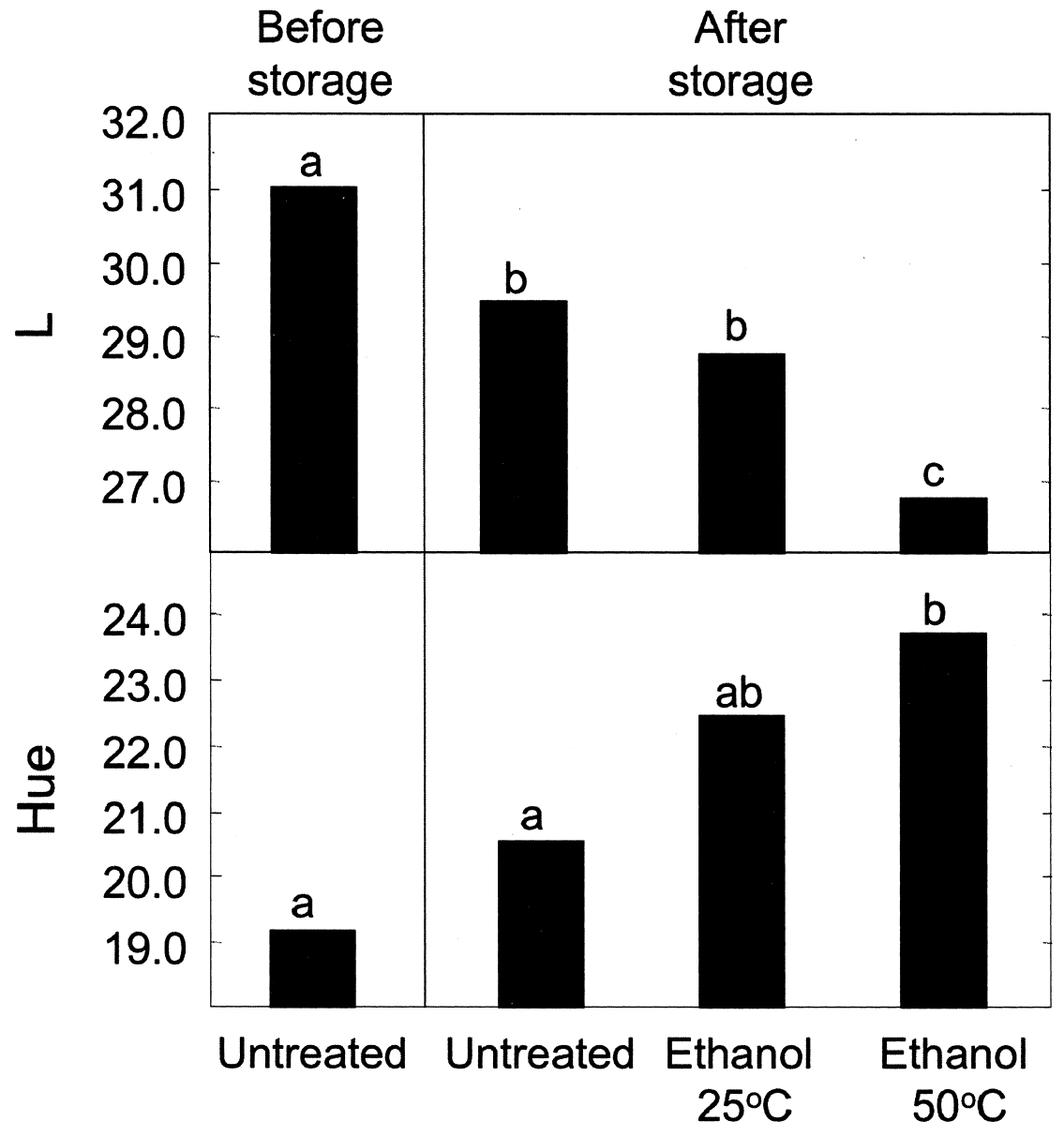

Fig. 6. Color of Crimson Seedless grape berries expressed as L and hue angle. Color was recorded before and after immersion of the berries in $30 \%$ ethanol at 25 or $50^{\circ} \mathrm{C}$, followed by 30 days of storage at $0.5^{\circ} \mathrm{C}$. contact with heat; however, when fruit are immersed in ethanol, the contact time is actually longer than the duration of the treatment and persists until the fruit are dry (20).

Increasing the temperature of many microbial biocides enhances their potency by two- to threefold for every $10^{\circ} \mathrm{C}$ increase in temperature, until thermal destruction of the microbe occurs (19). Recently, we quantified and modeled the effectiveness of various combinations of ethanol and heat to control the germination of spores of four postharvest pathogens (28). For example, a 30 -s exposure to $10 \%$ (vol/vol) ethanol at $35^{\circ} \mathrm{C}$ did not inhibit germination of spores of $B$. cinerea but, when it was heated to $45^{\circ} \mathrm{C}$, it completely inhibited their germination. The mode of lethal action of ethanol is thought to be a result of decreases in the transition temperatures of fungal membrane lipids and increases in their fluidity (27). According to CabecaSilva and coworkers (8), the primary sites of action of both heat and ethanol are mitochondrial membranes. The addition of $5 \%(\mathrm{vol} / \mathrm{vol})$ ethanol to liquid media containing Saccharomyces cerevisiae lowered the temperatures where growth, death, and the incidence of mutants with deficient mitochondria ("petite mutations") occurred. By combining hot water and ethanol in a single treatment, it is possible to reduce both the temperature of the water and the concentration of ethanol and still maintain the effectiveness. Consequently, the phytotoxicity of the high temperatures needed for pathogen inactivation could be avoided and, at the same time, ethanol concentrations could be reduced. Margosan et al. (23) demonstrated a synergistic effect of heat and ethanol when they reported that heated, dilute ethanol treatments controlled postharvest decay of strawberry caused by $B$. cinerea and Rhizopus stolonifer. Immersion of fruit in 10 or $20 \%$ (vol/vol) heated ethanol (46 to $50^{\circ} \mathrm{C}$ ) for up to $2.5 \mathrm{~min}$ effectively controlled green mold on lemons caused by $P$. digitatum and brown rot on peaches and nectarines caused by Monilinia fructicola $(24,38)$.

The addition of ethanol to water reduces its surface tension and facilitates better contact and penetration of the solution to the parts of the berry where pathogen resides. In addition to enhanced toxicity to $B$. cinerea, heat increased the amount of ethanol that penetrated into the berries. Cabras et al. (9) stated that increasing the temperature of many chemical solutions enables them to better diffuse through the cuticles of fresh fruit. In our work, ethanol heated to $50^{\circ} \mathrm{C}$ was the most effective treatment and it was associated with higher ethanol residues, which provides evidence of heat-facilitated penetration of ethanol into the berries. However, the concentration of ethanol residues was relatively low within the berries. It is unlikely the resi- 
dues alone were sufficient to inhibit fungal growth after treatment and did not protect the berries from subsequent infection.

Heat treatment has been reported to induce many plant-defense mechanisms such as accumulation of phytoalexins, pathogenesis-related proteins, and lignin-like materials, causing the treated fruit to become more resistant to subsequent infections (35). Conversely, we found that berries treated by $35 \%$ (vol/vol) ethanol at 25 or $50^{\circ} \mathrm{C}$ or with water at $50^{\circ} \mathrm{C}$ were slightly, but significantly, more susceptible to gray mold infection after inoculation than those that had not been treated. This indicates that no disease resistance was induced by these treatments. This result agrees with the observations of Lichter et al (20) that there is no evidence that ethanol and heat treatments induced resistance to infection, as measured by the induction of HSP101 proteins in Thompson Seedless berries. A practical consequence of this result is that treated berries must be protected from inoculum deposited after treatment. Berries were also more susceptible to subsequent infection after fumigation with sulfur dioxide, which caused microscopic injuries to the berry skin that facilitated $B$. cinerea infection (33). Another phenomenon caused by the heat treatments and observed with other fruit is a change in the appearance and flattening of the epicuticular wax platelets (35). That was not observed in our work with grape.

Conidia germinated faster when they were deposited on wounded tissue without the skin. Few germ tubes were present $24 \mathrm{~h}$ after inoculation when conidia were deposited on intact berry surface, whereas those deposited on wounds formed germ tubes that grew into the berry tissue. We found that only $3 \%$ of the conidia deposited on the berry skin germinated. Similarly, Coertze and Holz (10) found that less than $2 \%$ of berry skin segments were penetrated by conidia of $B$. cinerea deposited on the skin. The skin of grape berries is the major barrier to fungal penetration and infection processes. Cuticular fractures have been associated with increased susceptibility of grape berries to infection with $B$. cinerea (31). Therefore, the higher incidence of decay in berries that were inoculated after their pedicel was removed was expected. What is interesting is that heated ethanol was still effective up to $48 \mathrm{~h}$ after inoculation, even though the pathogen was able to germinate quickly and to penetrate the host, in berries inoculated with the pedicel removed. It is possible that the lack of skin enabled better penetration of the heated ethanol, resulting in greater activity on the pathogen.

The color of Crimson Seedless grape berries immersed in heated ethanol was darker and appeared more intense that of berries untreated or immersed in cool ethanol, when measured after 30 days of cold storage. The hue angle increased slightly but significantly, which indicates a progression in berry color toward brown, although this was not visible to the naked eye. The color change probably was caused by the heat component of the treatment, because cool ethanol did not change the color of the grape fruit. Underhill and Critchley (40) reported lychee pericarp browning, caused by heat treatments, that was a result of the degradation of anthocyanins due to increased polyphenol oxidase activity.

The elevated ethanol and acetaldehyde contents in grape juice after heated ethanol treatments were within the range naturally present in many fresh fruit. For example, the natural ethanol and acetaldehyde contents of May Grand and Red Diamond nectarine fruit stored for 6 days at $15^{\circ} \mathrm{C}$ were 200 and $230 \mu \mathrm{g} / \mathrm{ml}$ of ethanol and 6 and $5.8 \mu \mathrm{g} / \mathrm{ml}$ of acetaldehyde, respectively (36). At harvest, late-season Valencia orange fruit had ethanol and acetaldehyde contents that exceeded 600 and $6 \mu \mathrm{g} / \mathrm{ml}$, respectively. These values more than doubled after storage for 2 months (11).

The initial ethanol and acetaldehyde contents of untreated Crimson Seedless grape berries were about 60 and $1.2 \mu \mathrm{g} / \mathrm{g}$, respectively, and similar to those in Italia grape berries reported by Massignan and coworkers (25). We observed that after heated-ethanol treatment, the ethanol content of Crimson Seedless berries increased to $377 \mu \mathrm{g} / \mathrm{g}$ and declined during storage. After heated-ethanol treatment, the acetaldehyde content of the berries increased to $10 \mu \mathrm{g} / \mathrm{g}$, and persisted or increased slightly during storage. Increased acetaldehyde probably was caused by the oxidation of ethanol residues deposited by the ethanol treatment, or by the reduction of pyruvate that may have accumulated as a result of anaerobic respiration. Anaerobic respiration in the fruit would be a consequence of changes to mitochondria caused by the heat and ethanol treatment, which would inhibit aerobic metabolism. Heated-ethanol treatments disrupted mitochondria and induced petite mutants, which lack mitochondria, in S. cerevisiae (8).

De Kock and Holz (12) stated that postharvest decay of grape berries was due largely to infection by $B$. cinerea during storage by inoculum present in bunches at veraison or later stages. Preharvest fungicides alone did not prevent infection during storage. Because berries become infected primarily during harvest, packing operations, and storage, the necessity for reducing $B$. cinerea inoculum on harvested grape berries should be emphasized (13). Sanitizing grape berries in ethanol solutions could be particularly useful for the postharvest treatment of grape berries marketed under "organic" classifications, where sulfur dioxide treatments are prohibited and grape fruit are stored and marketed without any protection from postharvest decay. Sulfur dioxide fumigation would not be a suitable treatment for packages containing single berries with their pedicels detached, because this opening provides an entry point for the accumulation of excessive sulfur dioxide residues, probably above the tolerance of $10 \mu \mathrm{g} / \mathrm{g}$, and unsightly bleaching of the berries would occur (37). Ethanol treatment of those berries is promising. An additional benefit from ethanol treatment would be the cleaning of the grape berries. That is especially important for the late ripening cultivars because, late in the season, they can have visible deposits of dust and insect frass.

\section{ACKNOWLEDGMENTS}

We thank grower J. France for providing fresh grape berries and his interest and encouragement to conduct this work.

\section{LITERATURE CITED}

1. Anon. 1986. GRAS status of sulfating agents for use on fresh and frozen foods revoked. Fed. Regist. 51:25021.

2. Anon. 1989. Pesticide tolerance for sulfur dioxide. Fed. Regist. 54:20125-20126.

3. Anon. 2003. NIOSH Pocket Guide to Chemical Hazards. United States Government Printing Office, Washington, DC.

4. Austin, A. K., Clay, W., Phimphiwong, S. Smilanick, J. L., and Henson, J. D. 1997. Patterns of sulfite residues in grapes during three months of repeated sulfur dioxide fumigations. Am. J. Enol. Vitic. 48:121-124.

5. Baker, C. J., and Bateman, D. F. 1978. Cutin degradation by plant pathogenic fungi. Phytopathology 68:1577-1584.

6. Barkai-Golan, R. 2001. Postharvest diseases of fruits and vegetables. Development and control. Elsevier Science, B. V. Amsterdam, The Netherlands.

7. Barkai-Golan, R., and Phillips, D. J. 1991. Postharvest heat treatments of fresh fruits and vegetables for decay control. Plant Dis. 75:1085-1089.

8. Cabeca-Silva, C., Madeira-Lopes, A., and van Unden, N. 1982. Temperature relations of ethanol-enhanced petite mutation in Saccharomyces cerevisiae: mitochondria as targets of thermal death. FEMS Microbiol. Lett. 15:149-151.

9. Cabras, P., Schirra, M., Pirisi, F. M., Garau, V L., and Angioni, A. 1999. Factors affecting imazalil and thiabendazole uptake and persistence in citrus fruits following dip treatments. J. Agric. Food. Chem. 47:3352-3354.

10. Coertze, S., and Holz, G.. 1999. Surface colonization, penetration, and lesion formation on grapes inoculated fresh or after cold storage with single airborne conidia of Botrytis cinerea. Plant Dis. 83:917-924.

11. Davis, P. L. 1971. Further studies of ethanol and acetaldehyde in juice of citrus fruits during the growing season and during storage. Proc. Fla. State Hortic. Soc. 84:217-222.

12. De Kock, P. J., and Holz, G. 1991. Colonization of table grapes by Botrytis cinerea in the Western Cape province. Phytophylactica 23:73-80.

13. De Kock, P. J., and Holz, G. 1994. Application of fungicides against postharvest Botrytis cinerea bunch rot of table grapes in the Western Cape. S. Afr. J. Enol. Vitic. 15:33-40.

14. El Kereamy, A., Chervin, C., Souquet, J.-M., M. Moutounet, M., Monje, M.-C., Nepveu, F. Mondies, H., Ford, C. M., van Heeswijck, R., and Roustan, J.-P. 2002. Ethanol triggers grape gene expression leading to anthocyanin accumulation during berry ripening. Plant Sci. 163:449-454. 
15. Fallik, E., Grinberg, S., Alkalai, S., and Lurie, S. 1996. The effectiveness of postharvest hot water dipping on the control of grey and black moulds in sweet red pepper (Capsicum annuum). Plant Pathol. 45:644-649.

16. Gorini, F. Lasorella, M., and Tonno A. 1990. Heat treatment as prevention of postharvest diseases. Riv. Fruttic. Ortofloric. 52:17-26.

17. Karabulut, O. A., Mlikota Gabler, F., Mansour, M., and Smilanick, J. L. 2004. Postharvest ethanol and hot water treatments of table grapes to control gray mold. Postharvest Biol. Technol. 36:169-176.

18. Karabulut, O. A., Smilanick, J. L., Mlikota Gabler, F., Mansour, M., and Droby, S. 2003. Near-harvest applications of Metschnikowia fructicola, ethanol, and sodium bicarbonate to control postharvest diseases of grape in central California. Plant Dis. 87:1384-1389.

19. Kostenbauder, H. B. 1991. Physical factors influencing the activity of antimicrobial agents. Pages 59-71 in: Disinfection, Sterilization and Preservation. S. S. Block, ed. Lea \& Febiger, Philadelphia

20. Lichter, A., Zhou, H.-W., Vaknin, M., Dvir, O., Zutchi, Y., Kaplunov, T., and Lurie, S. 2003. Survival and responses of Botrytis cinerea after exposure to ethanol and heat. J. Phytopathol. 151:553-563.

21. Lichter, A., Zutchy, Y., Sonego, L., Dvir, O., Kaplunov, T., Sarig, P., and Ben-Arie, R. 2002. Ethanol controls postharvest decay of table grapes. Postharvest Biol. Technol. 24:301-208.

22. Luvisi, D. A., Shorey, H. H., Smilanick, J. L., Thompson, J. F., Gump, and B. H. Knutson, J. 1992. Sulfur dioxide fumigation of table grapes. Univ. Calif. Div. Agric. Sci. Publ. No. 1932.

23. Margosan, D. A., Smilanick, J. L., and Simmons, G. F. 1994. Hot ethanol treatment for the postharvest control of gray mold and black rot of strawberries. Biol. Cult. Tests
Control Plant Dis. 10:60.

24. Margosan, D. A., Smilanick, J. L., Simmons, G. F., and Henson, D. J. 1997. Combination of hot water and ethanol to control postharvest decay of peaches and nectarines. Plant Dis. 81:1405-1409.

25. Massignan, L., De Leo, P., La Notte, E., and Gambacorta, G. 1984. Influenzia della frigoconservazione in atmosfera controllata su alcune caractterisciche qualitative dell'uva da tavola. Industria Conserve 59:130-135.

26. McGuire, R. G. 1992. Reporting of objective color measurements. HortScience 27:12541255 .

27. Mishra, P. 1993 Tolerance of fungi to ethanol. Pages 189-208 in: Stress Tolerance of Fungi D. H. Jennings, ed. Marcel Dekker Inc., New York.

28. Mlikota Gabler, F., Mansour, M. F., Smilanick, J. L., and Mackey, B. E. 2004. Survival of spores of Rhizopus stolonifer, Aspergillus niger, Botrytis cinerea and Alternaria alternata after exposure to ethanol solutions at various temperatures. J. Appl. Microbiol. 96: 13541360.

29. Mlikota Gabler, F., and Smilanick, J .L. 2001. Postharvest control of table grape gray mold on detached berries with carbonate and bicarbonate salts and disinfectants. Am. J. Enol. Vitic. 52:12-20.

30. Mlikota Gabler, F., Smilanick, J. L., Aiyabei, J., and Mansour, M. 2002. New approaches to control postharvest gray mold (Botrytis cinerea Pers.) on table grapes using ozone and ethanol. Page 78 in: Proc. World of Microbes, Xth Int. Congr. Mycol. Paris.

31. Mlikota Gabler, F., Smilanick, J. L., Mansour, M., Ramming, D. W., and Mackey, B. E. 2003. Correlations of morphological, anatomical, and chemical features of grape berries with resistance to Botrytis cinerea. Phytopathology 93:1263-1273.

32. Nelson, K. E. 1985. Harvesting and handling
California table grapes for market. Univ. Calif. Div. Agric. Sci. Publ. No. 1913

33. Nelson, K. E., and Tomlinson, F. E. 1958. Some factors influencing bleaching and wetness of Emperor and Tokay grapes. Proc. Am Soc. Hortic. Sci. 71:190-198.

34. Percival, D. C., Sullivan, J. A., and Fisher, K. H. 1993. Effect of cluster exposure, berry con tact and cultivar on cuticular membrane formaion and occurrence of bunch rot (Botrytis cinerea Pers.:Fr.) with 3 Vitis vinifera $\mathrm{L}$. cultivars. Vitis 32:87-97.

35. Schirra, M., D'Hallewin, G., Ben-Yehoshua, S., and Fallik, E. 2000. Host-pathogen interactions modulated by heat treatment. Postharvest Biol. Technol. 21:71-85.

36. Smilanick, J. L., and Fouse, D. C. 1989. Quality of nectarines stored in insecticidal low $\mathrm{O} 2$ atmospheres at 5 and 15C. J. Am. Soc. Hortic. Sci. 114:431-436.

37. Smilanick, J. L., Harvey, J. M., Hartsell, P. L., Hensen, D. J., Harris, C. M., Fouse, D. C., and Assemi, M. 1990. Factors influencing sulfite residues in table grapes after sulfur dioxide fumigation. Am. J. Enol. Vitic. 41:131-136.

38. Smilanick, J .L, Margosan, D. A., and Henson, D. J. 1995. Evaluation of heated solutions of sulfur dioxide, ethanol, and hydrogen peroxide to control postharvest green mold of lemons. Plant Dis. 79:742-747.

39. Smilanick, J. L, Sorenson, D., Mansour, M Aiyabei, J., and Plaza, P. 2003. Impact of brief postharvest hot water drench treatment on decay, fruit appearance, and microbe population of California lemons and oranges. HortTechnology 13:333-338.

40. Underhill, S. J. R., and Critchley, C. 1993 Lychee pericarp browning caused by heat injury. HortScience 28:721-722.

41. USDA National Organic Program. 2001. The national list of allowed and prohibited substances. United States Code of Federal Regulations 7, part 205-601. 